\title{
Xenia and metaxenia in hazelnuts: Effects of pollinizer cultivars on nut set and nut characteristics of some hazelnut cultivars*
}

\author{
Hüseyin İrfan BALIK ${ }^{1}$, Neriman BEYHAN ${ }^{2} 2$ \\ 1Sakarya University of Applied Science, Faculty of Agricultural Sciences and Technologies, Department of Horticulture, Sakarya \\ ${ }^{2}$ Ondokuz Mayıs University Faculty of Agriculture, Department of Horticulture, Samsun
}

*This study was prepared from a part of the doctoral dissertation named 'Investigations of Xenia and Metaxenia in Hazelnut'.

Alınış tarihi: 9 Mayıs 2019, Kabul tarihi: 26 Ağustos 2019

Sorumlu yazar: Hüseyin İrfan BALIK, e-posta: h.irfanbalik@gmail.com

\begin{abstract}
This study has been conducted between 2015 and 2016 at Hazelnut Research Institute in Giresun. The objective of this study was to determine the effects of the pollinizer cultivars on the nut and kernel characteristics. Tombul, Palaz, Çakıldak, Foşa and Allahverdi were used as main cultivars while Tombul, Palaz, Çakıldak, Foşa, Allahverdi, Sivri, Kalınkara and Yassı Badem were used as pollinizer cultivars. Self-pollination was considered as a control and open-pollination was taken as an application. In the study, it was determined that the pollinizer cultivars caused changes in some nut and kernel characteristics with the xenia and metaxenia effects. The effects of pollinizers on nut set and number of nut in clusters were quite obvious. Selfpollination resulted in low nut set and number of nut in clusters, indicating it is self-incompatible. Open pollination and different cross-pollination treatments increased nut set and number of nut in clusters. It is estimated that the changes in the pomological characteristics may be related to the nut set as well as the pollen sources. The kernel percentage and good kernel were generally low in self-pollination. Open-pollination and crosspollination treatments increased kernel percentage and good kernel. It has also been improved that the pollinizer cultivars may cause changes in nut shape. Palaz pollination treatment caused decrease of nut shape index in main cultivars.
\end{abstract}

Key words: Corylus avellana, pollinizer, xenia, metaxenia, nut characteristics, yield
Findıkta kseni ve metakseni: meyve tutumu ve meyve özelliklerine etkisi

Öz

Bu çalışma 2015 ve 2016 yıllarında Fındık Araştırma Enstitüsü (Giresun) deneme bahçelerinde yürütülmüştür. Çalışmada fındıkta tozlayıcı çeşitlerin meyve ve iç özelliklerinde sebep olduğu değișimlerin belirlenmesi amaçlanmıştır. Ana çeşit olarak Tombul, Palaz, Çakıldak, Foşa ve Allahverdi; tozlayıcı çeşit olarak ise bu beş çeşide ilave olarak Sivri, Kalınkara ve Yassı Badem kullanılmıștır. Kendileme, kontrol olarak kabul edilmiș, serbest tozlanma ise uygulama olarak değerlendirmeye alınmıștır. Çalışmada, tozlayıcı çeșitlerin kseni ve metakseni etkisi ile bazı meyve ve iç özelliklerinde değişikliklere sebep olduğu tespit edilmiştir. Uygulamaların karanfilin çotanağa dönüșüm oranı (meyve tutumu) ile çotanaktaki meyve sayısına etkileri oldukça belirgin olmuștur. Kendine uyușmazlığın göstergesi olarak kendilemede genellikle meyve tutumu ve çotanaktaki meyve sayısı düşük tespit edilmiştir. Açık tozlanma ve karşlıklı tozlanma uygulamaları meyve tutumu ve çotanaktaki meyve sayısının artmasına neden olmuştur. Pomolojik özelliklerde meydana gelen değişimlerin çiçek tozu kaynağının yanı sıra meyve yükü ile de ilişsili olabileceği değerlendirilmiştir. Kendilemede iç oranı ve sağlam iç oranı düşük iken, açık tozlanma ve karşlıklı tozlanma uygulamasında genellikle yüksek tespit edilmiştir. Ayrıca, tozlayıcı çeşitlerin 
meyve șeklinde değişikliklere sebep olduğu kanıtlanmıştır. Palaz'ın tozlayıcı olduğu uygulamalarda meyve şekil indeksi azalmıştır.

Anahtar kelimeler: Corylus avellana, tozlayıcl, kseni, metakseni, meyve özellikleri

\section{Introduction}

Hazelnuts are monoecious, meaning they have separate male and female flowers on the same plant, but at different places. There are self and reciprocal incompatibilities in hazelnuts. Incompatibility in hazelnut is sporophytic-type controlled by a single locus and S alleles (Thompson, 1979). Male and female flowers are ripened and bloomed at different times. Blooming time and duration of male and female flowers vary with the ecology, cultivars and years in the same cultivar (Beyhan, 2000). Flowering initiation dates and blooming durations are closely related to climate factors, especially to temperature. Blooming starts earlier in regions with mild winters. Recent high temperatures in autumn and winter months led blooming of male flowers (catkins) with lower chilling requirements earlier than the female flowers and thus dichogamy levels of the cultivars increase.

Pollination and fertilization are obligatory in hazelnut for nut formation. Thus, incompatibility and dichogamy mechanisms bring selection of pollinizer cultivar forward (Balık and Beyhan 2011).

Several researchers have brought different definitions for xenia and metaxenia (Kirkpatrick, 1987; Morris, 1976; Neufeldt, 1988; Reiger et al., 1976; Soule, 1985; Westwood, 1989; Winburne, 1962). However, xenia for the first time defined by Focke (1881), as changes occurred in tissues of mother through pollen effect. Swingle (1928) defined xenia as the changes occurred in embryo and endosperm through pollen effect and defined the changes occurred in mother tissues as metaxenia. Denney (1992) defined xenia as the changes occurred in shape, color, ripening time and chemical composition of seed and fruit. Such conceptual confusions about xenia and metaxenia has clarified with the invention of double-fertilization by Strasburger (1878) and Navaschin (1898). Both researchers defined double-fertilization as fertilization of ovary cell in embryonic sac by one of male gametes and fertilization of polar nuclei by the other male gamete. Following the invention of double-fertilization, it was proved that such pollination resulted in changes in endosperm (mother tissues) through pollen effect. Therefore, following the invention of double-fertilization, the term "xenia" was defined as the changes occurred in embryo, endosperm and all mother tissues through pollen effect.

In this study, effects of different pollination treatments on nut set and nut characteristics of hazelnut were investigated.

\section{Material and Methods}

This study was conducted under ecological conditions of Giresun province in the years 2015 and 2016. Experimental plots were constructed in multibushed system (ocak system) established at $3 \times 3 \mathrm{~m}$ spacing in 1994. Tombul, Palaz, Çakıldak, Foşa and Allahverdi were used as main cultivar (Round group). These cultivars were controlled-pollinated with Sivri (Pointed group), Kalınkara (Round group) and Yassı Badem (Long Group) cultivars (İslam, 2018). Self-pollination and open-pollination were practiced. Experiments were conducted in randomized blocks design with 3 replications and with 3 plants (bushes) in each replicate. Selfpollination was as the control treatment while openpollination was considered as a treatment.

Experimental site has a soil texture of clay-loam with a pH of 4.78 and organic matter content of $4.58 \%$. The site is located at $40^{\circ} 54^{\prime} 31^{\prime \prime}$ North and $38^{\circ} 21^{\prime}$ 09" East coordinates and has an altitude of $5 \mathrm{~m}$. Annual total precipitation is over $1200 \mathrm{~mm}$ and annual average temperature is $15^{\circ} \mathrm{C}$.

\section{Emasculation, Isolation and Pollen Collection}

In plants of main cultivars to be controlledhybridized, male flowers (catkins) were removed as specified by Erdoğan and Mehlenbacher (1997).

Plants of main cultivars were surrounded by $4 \mathrm{~m}$ high and $4 \mathrm{~m}$ wide iron constructions and entire plant was encapsulated within this framework and covered with tyvek. Tyvek, which is a durable material, has been used for many years in crossing studies in hazelnuts. Because of the flowering period in hazelnuts is quite long, it is necessary to use isolation materials that are durable, strong, which prevent the passage of pollen and which have air permeability (Smith and Mehlenbacher, 1994).

When the catkins of pollinizer cultivars started to be elongated, they were carefully cut together with the shoot bearing catkins, then they were placed in water-filled glass jars and kept at room temperature for 24 hours. Each cultivar was kept in different 
room to prevent undesired pollen transfers. Following 24 hours, catkins were shaken over a black paper, pollens were sieved through $125 \mu$ sieve and transferred to preservation cups. Pollens were preserved in a deep freezer at $-18^{\circ} \mathrm{C}$ until the use.

\section{Controlled pollinations}

When the female flowers of main cultivars become receptive, pollens preserved in deep freezer were used to perform crossings. Stigmatic styles can accept pollens as soon as they went out of florets, but it was waited until these styles got a shiny red color for an effective pollination. The pollens stored in preservation cups in a deep freezer were transferred to eppendorph tubes at the day of pollination. Lid of eppendorph tube was opened, the tube turned upside down and flower pollens were taken over the index finger. Then artificial pollination was performed through touching to styles of the florets with the index finger. One week after hydridizations, browning was observed in floret styles.

\section{Nut set}

To determine the effects of pollinator types on nut set, 3 plants (bushes) orienting different directions were selected from 3 different multibush system (ocak) for each crossing combination and number of female flowers over which crossings were performed was recorded.

\section{Nut characteristics}

When the main cultivars reached to harvest maturity, nuts were harvested from each combination and they were placed into labeled sacks. Harvest criteria were considered as; husks turned into yellow, reddish and brown color, reddish color of $3 / 4$ of nut hard shell. From each material combination, 100 husks were randomly selected, and number of nuts per cluster was determined, then nuts were removed from the husk and dried over concrete floor under the sun.

Nut and kernel weight were determined with a precise scale $( \pm 0.01 \mathrm{~g})$; shell thickness, kernel cavity and nut size were determined with a caliper $( \pm 0.01$ $\mathrm{mm})$. Kernel percentage and good kernel were calculated over 100 nuts and expressed in \%. Nut shape index was calculated with the aid of average nut length, width and thickness.

\section{Statistical analyses}

Experimental data were subjected to statistical analyses with the aid of SAS Version 9.1 software. Percent values (\%) were subjected to angle (arcsine) transformation and then subjected to statistical analyses. Significant means were compared with the aid of Duncan's multiple range test at $5 \%$ level $(\mathrm{P}<0.05)$. Data were subjected to analysis of variance separately for each year.

In 2015, no data was obtained in Palaz x Kalınkara crossings.

\section{Results and Discussion}

\section{Nut set}

In 2015, effects of pollination treatments on nut set were significant in all cultivars except for Allahverdi. In 2016, effects of treatments on nut set of all cultivars were found to be significant $(\mathrm{P}<0.05)$. In the first year of the experiments (2015), the lowest nut set values were observed in self-pollination treatments of Palaz and Çakıldak cultivars. In 2016, besides Palaz and Çakıldak cultivars, the lowest nut set values were also observed in self-pollination treatments of Tombul and Allahverdi cultivars. Therefore, it can be stated that cross pollinations increased nut sets in both years (Table 1-10). Fatahi et al. (2014) indicated that cross pollinations significantly increased nut set of hazelnut cultivars. De Nettancourt (1977) indicated that low nut set of self-pollination treatments was the indicator of selfincompatibility. Çakır and Genç (1979) reported nut set as $27.5 \%$ for self-pollination of Tombul cultivar, $52 \%$ for Tombul x Palaz pollination treatment, $51 \%$ for Palaz x Yabani Sivri pollination treatment, $46 \%$ for Çakıldak $\mathrm{x}$ Tombul pollination combination and indicated that cross pollinations increased nut set of hazelnuts. On the other hand Xie and Liu (2014) pointed out that fertile efficiency increased when the pollen vigor was high. Erdoğan and Mehlenbacher (2001) indicated that low nut set of self-pollination treatments in hazelnut mostly resulted from selfincompatibility and defined the indicators of incompatibility as low germination ratios of pollen in stigma, short and curly nature of pollen tube. Despite the incompatibility in several combinations, low nut sets in field experiments were attributed to pollen germination and development of pollen tube, as well as failures in pollen germination and intrusion of pollen tube into style, damage of pollen tube in style with the impact of pollination, embryo abortion, endosperm defects and hybrid deterioration as indicated by Lield and Anderson (1993). Olsen et al. (2000) indicated that there was self and cross incompatibility in hazelnut and such incompatibilities were sporophytic type controlled by a single locus and S alleles. Beyhan and Marangoz 
(2007) indicated the reasons of cluster drops outs as genetic structure, periodicity, pollen source, incompatibility, cultural practices and environmental conditions.

\section{Number of nuts per cluster}

Effects of treatments on number of nuts per cluster were significant. In 2015, the lowest number of nuts per cluster was observed in self-pollination treatments of Tombul, Palaz, Çakıldak and Allahverdi cultivars. In 2016, the lowest number of nuts per cluster was also observed in self-pollination treatments of Tombul, Palaz, Foşa and Allahverdi cultivars (Table 1-10). Therefore, it is possible to state that cross pollinations may improve the number of nuts per cluster and thus increase yields to some extent. The low level of number of nuts per cluster in self-pollination is considered as an indicator of self-incompatibility. In some Turkish hazelnut cultivars, number of nuts per cluster varies between 1.1 and 4.8. Number of nuts per cluster was 3.8 for Tombul, 3.2 for Palaz, 1.7 for Çakıldak, 2.2 for Foşa and 3.2 for Allahverdi cultivars (Köksal, 2002; Okay et al., 1999).

İslam et al. (2005) indicated decreasing nut size, shell thickness and space between shell and kernel with increasing number of nuts per cluster in hazelnut. Balık et al. (2014) indicated number of nuts per cluster as a cultivar characteristic and stated that values may vary from year to year; lower number of nuts per cluster reduced the yield and greater number of nuts per cluster resulted in deformity in nut shape, decreased nut and kernel sizes. Heredity of number of nuts per cluster was reported as 0.67 by Yao and Mehlenbacher (2000).

\section{Nut weight}

In 2015, effects of treatments on nut weight were significant in all of the main cultivars $(\mathrm{P}<0.05)$. The lowest nut weight values were observed in openpollination treatments of Tombul, Palaz, Çakıldak and Allahverdi cultivars. In 2016, effects of treatments on nut weight were found to be significant in all cultivars, except for Tombul. Effects of treatments on nut weight of Tombul were not found to be significant (Table 1-10).

In 2015, open-pollination treatments had lower nut weight in Tombul, Palaz, Çakıldak, Foşa and Allahverdi cultivars. Except for Tombul cultivar, Palaz-pollination treatments yielded the greatest nut weight in the other cultivars. In 2016, Tombulpollination treatments yielded the lowest nut weight in Palaz, Foşa and Allahverdi cultivars. In the second year of the experiments, Allahverdi, Sivri and Kalınkara-pollination treatments generally yielded greater nut weight. Open-pollination treatments generally yielded lower yielded values.

\section{Kernel weight}

In 2015, effects of treatments on kernel weight were significant $(\mathrm{P}<0.05)$. In 2015, Palaz-pollination treatments yielded high kernel weight and openpollination treatments yielded low kernel weight.

In 2016, effects of treatments on kernel weight were significant in all cultivars, except for Tombul $(\mathrm{P}<0.05)$. As it was in nut weight of 2015 , openpollination treatments yielded lower kernel weight than the other pollination treatments. A similar case was also observed in the second year of the experiments. Palaz and Kalınkara-pollination treatments in 2015 and Sivri and Kalınkarapollination treatments in 2016 yielded greater kernel weight in all cultivars (Table 1-10). Vezvaei and Jackson (1995) conducted a study on almonds and reported that pollinator cultivars increased nut weight, but did not have significant effects on kernel weight. On the other hand, Legave et al. (1997) and Dicenta et al. (2002) indicated that cross pollinations did not have significant effects on nut weight, kernel weight, kernel percentage, double kernel, blank nut and cracked nut of almonds. Anagnostakis and Devin (1998) reported that large nuts were obtained from small-nut chestnut cultivars of Sleeping Giant, Eaton, Little Giant, Amer 1 and Amer 2 through pollinations with large-nut Lockwood cultivars; smaller nuts were obtained from small-nut Little Giant cultivar through pollinations with large-nut Sleeping Giant, Eaton, Lockwood, Amer 1 and Amer 2 cultivars. Therefore, researchers indicated that nut weight in chestnut did not varied with the pollen source and nut weight was a characteristic of main cultivar.

\section{Shell thickness}

Effects of treatments on shell thickness were significant in both years $(\mathrm{P}<0.05)$. In 2015 , shell thickness was generally low in open-pollination treatments and high in self-pollination treatments.

In 2015, low shell thickness of open-pollination treatments was quite remarkable. The greatest shell thickness values were observed in self-pollination treatments of Tombul and Çakıldak cultivars. Kalınkara-pollination treatments increased shell thickness in all cultivars. In Çakıldak, Foşa and 
Allahverdi cultivars, pollinations with Tombul and Palaz yielded greater shell thickness. In 2016, Tombul, Palaz, Çakıldak and Allahverdi cultivars had greater shell thickness values in self-pollination treatments (Table 1-10). Balı et al. (2016) reported shell thickness as $0.90 \mathrm{~mm}$ for Tombul, $0.95 \mathrm{~mm}$ for Palaz, $0.84 \mathrm{~mm}$ for Çakıldak, $0.84 \mathrm{~mm}$ for Foşa and $0.89 \mathrm{~mm}$ for Allahverdi cultivars. Ak (2001) indicated that nut weight, nut width and shell thickness of pistachio generally varied with the pollinators. Owais (2014) indicated that pollen source resulted in slight changes in shell, nut and kernel characteristics of almonds. Golzari et al. (2016) reported significant effects of pollinator types on kernel diameter, kernel weight, shell thickness, oil and protein ratio of walnuts.

\section{Kernel cavity}

In 2015, effects of treatments on kernel cavity were significant $(\mathrm{P}<0.05)$. Contrary to 2015 , effects of treatments on kernel cavity were not significant in Çakıldak and Allahverdi cultivars in 2016. The kernel cavity was generally larger in cultivars with circular type of nuts. Kernel cavity increased or decreased based on kernel size. In both years of the experiments, Palaz and Foşa cultivars had greater kernel cavity than the other cultivars. Pollination treatments with larger nut sizes also yielded greater kernel cavities (Table 1-10). Balık et al. (2014) indicated that small kernels had either small or any kernel cavities. Researchers also indicated that blanching or browning of kernel cavity varied with the years, browning increased in time with storage conditions and bitterness initiated in such kernel cavities after a certain time period. Romero et al. (2003) reported greater browning in kernel cavities in warming years. Balık et al. (2016) reported kernel cavity as $1.51 \mathrm{~mm}$ for Tombul, $3.25 \mathrm{~mm}$ for Palaz, $2.02 \mathrm{~mm}$ for Çakıldak, $2.26 \mathrm{~mm}$ for Foşa and 2.23 $\mathrm{mm}$ for Allahverdi cultivars.

\section{Kernel percentage}

Effects of treatments on kernel percentages were significant in both years $(\mathrm{P}<0.05)$. Kernel percentages were generally lower in combinations with thicker shells and greater kernel cavities and vice versa. It is remarkable that self-pollination treatments had generally low kernel percentages in 2016. In 2015, the lowest kernel percentages were observed in self-pollination treatments of Tombul and Palaz cultivars. In 2016, besides Tombul and Palaz, the lowest kernel percentages in Allahverdi cultivar were also observed in self-pollination treatments. In both years of the experiments, openpollination treatments with lower shell thickness yielded greater kernel percentages. Besides, the treatments with low kernel cavity, nut and kernel weight generally had high kernel percentages (Table 1-10). There are some earlier studies indicating insignificant effects of pollinator types on kernel percentages of pistachios (Ak, 2001), almonds (Legave et al., 1997; Dicenta et al., 2002) and chestnuts (Xuhui et al., 2016). Balık et al. (2016) reported kernel percentages as $54.4 \%$ for Tombul, $51.4 \%$ for Palaz, $55.8 \%$ for Çakıldak, $50.2 \%$ for Foşa and $49.3 \%$ for Allahverdi cultivars.

\section{Good kernel}

In both years of the experiments (2015 and 2016), effects of treatments on good kernels were significant $(\mathrm{P}<0.05)$. Again, in both years of the experiments, self-pollination treatments generally yielded lower good kernels. The treatments with greater kernel percentages generally had greater good kernels (Table 1-10).

\section{Nut shape index}

Effects of treatments on nut shape index were significant in both years $(\mathrm{P}<0.05)$. In 2016, the lowest nut shape index values were observed in selfpollination treatments of Tombul, Palaz and Allahverdi cultivars and the greatest values were observed in self-polllination treatments of Çakıldak and Foşa cultivars. The variations of nut shape index of Palaz and Foşa cultivars with oblate nut shape were more limited as compared to the other cultivars. In Tombul, Çakıldak and Allahverdi cultivars, nut shape index of some combinations ranged from spherical-conical to oval shape. Variations in kernel shape index values were also similar with the variations in nut shape index values (Table 1-10). Çetiner et al. (1984) indicated that pointy nut shape of Sivri and İncekara cultivars with the greatest transformation ratio of florets into husk distorted homogeneity and product quality in hazelnut orchards. Owais (2014) indicated that pollinator types resulted in significant changes in shell shape of almonds. 
Table 1. Nut set, number of nuts per cluster and nut characteristics of Tombul hazelnut in response to different pollinizer cultivars in 2015 .

\begin{tabular}{|c|c|c|c|c|c|c|c|c|c|}
\hline $\begin{array}{l}\text { Pollinizer } \\
\text { cultivars }\end{array}$ & $\begin{array}{c}\text { Nut set } \\
(\%)\end{array}$ & $\begin{array}{l}\text { Number of } \\
\text { nuts } \\
\text { per cluster }\end{array}$ & $\begin{array}{l}\text { Nut weight } \\
\text { (g) }\end{array}$ & $\begin{array}{c}\text { Kernel } \\
\text { weight } \\
\text { (g) }\end{array}$ & $\begin{array}{l}\text { Shell } \\
\text { thickness } \\
(\mathrm{mm})\end{array}$ & $\begin{array}{l}\text { Kernel } \\
\text { cavity } \\
(\mathrm{mm})\end{array}$ & $\begin{array}{c}\text { Kernel } \\
\text { percentage } \\
(\%)\end{array}$ & $\begin{array}{l}\text { Good } \\
\text { kernel } \\
(\%)\end{array}$ & $\begin{array}{c}\text { Nut } \\
\text { shape } \\
\text { index }\end{array}$ \\
\hline Tombul & $62.33 \mathrm{ab}$ & $2.53 \mathrm{e}$ & $2.32 \mathrm{ab}$ & $1.21 \mathrm{ab}$ & $1.16 \mathrm{a}$ & $2.91 \mathrm{~b}$ & $52.31 \mathrm{~b}$ & $86.00 \mathrm{~b}$ & $1.14 \mathrm{bc}$ \\
\hline Palaz & $46.48 \mathrm{~cd}$ & $2.88 \mathrm{~d}$ & $2.16 \mathrm{bcd}$ & $1.15 \mathrm{ab}$ & $1.01 \mathrm{~cd}$ & $3.15 \mathrm{ab}$ & $52.92 \mathrm{~b}$ & $84.00 \mathrm{~b}$ & $1.07 \mathrm{~d}$ \\
\hline Çakıldak & $55.81 \mathrm{bc}$ & $3.98 \mathrm{~b}$ & $2.10 \mathrm{~cd}$ & $1.11 \mathrm{~b}$ & $1.10 \mathrm{abc}$ & $2.77 \mathrm{~b}$ & $52.43 \mathrm{~b}$ & $93.66 \mathrm{a}$ & $1.24 \mathrm{a}$ \\
\hline Foșa & $70.14 \mathrm{a}$ & $4.03 \mathrm{~b}$ & $2.12 \mathrm{~cd}$ & $1.12 \mathrm{ab}$ & $1.05 \mathrm{bcd}$ & $2.98 \mathrm{ab}$ & $52.82 \mathrm{~b}$ & $92.00 \mathrm{a}$ & $1.16 \mathrm{~b}$ \\
\hline Allahverdi & $49.94 \mathrm{~cd}$ & $4.28 \mathrm{a}$ & $2.24 \mathrm{abc}$ & $1.21 \mathrm{ab}$ & $1.11 \mathrm{ab}$ & $3.37 \mathrm{ab}$ & $54.09 \mathrm{ab}$ & $93.00 \mathrm{a}$ & $1.13 \mathrm{bc}$ \\
\hline Sivri & $45.68 \mathrm{~d}$ & $2.68 \mathrm{e}$ & $2.14 \mathrm{~cd}$ & $1.14 \mathrm{ab}$ & $1.03 \mathrm{bcd}$ & $3.37 \mathrm{ab}$ & $53.16 \mathrm{ab}$ & $93.10 \mathrm{a}$ & $1.09 \mathrm{~cd}$ \\
\hline Kalınkara & $51.58 \mathrm{~cd}$ & $3.37 \mathrm{c}$ & $2.35 \mathrm{a}$ & $1.24 \mathrm{a}$ & $1.11 \mathrm{ab}$ & $3.41 \mathrm{ab}$ & $52.85 \mathrm{~b}$ & $93.00 \mathrm{a}$ & $1.08 \mathrm{~cd}$ \\
\hline Yassı Badem & $70.45 a$ & $3.05 \mathrm{~d}$ & $2.38 \mathrm{a}$ & $1.23 \mathrm{a}$ & $1.11 \mathrm{ab}$ & $3.72 \mathrm{a}$ & $52.57 \mathrm{~b}$ & $85.00 \mathrm{~b}$ & $1.10 \mathrm{~cd}$ \\
\hline Open pollination & $63.62 \mathrm{ab}$ & $4.11 \mathrm{ab}$ & $2.06 \mathrm{~d}$ & $1.14 \mathrm{ab}$ & $0.99 \mathrm{~d}$ & $3.47 \mathrm{ab}$ & $55.30 \mathrm{a}$ & $92.00 \mathrm{a}$ & $1.13 \mathrm{bc}$ \\
\hline
\end{tabular}

The differences among the treatments indicated with the same letter vertically were not significant at $\mathrm{P}<0.05$.

Table 2. Nut set, number of nuts per cluster and nut characteristics of Tombul hazelnut in response to different pollinizer cultivars in 2016.

\begin{tabular}{|c|c|c|c|c|c|c|c|c|c|}
\hline $\begin{array}{l}\text { Pollinizer } \\
\text { cultivars }\end{array}$ & $\begin{array}{c}\text { Nut set } \\
(\%)\end{array}$ & $\begin{array}{l}\text { Number of } \\
\text { nuts } \\
\text { per cluster }\end{array}$ & $\begin{array}{c}\text { Nut } \\
\text { weight } \\
\text { (g) }\end{array}$ & $\begin{array}{c}\text { Kernel } \\
\text { weight } \\
\text { (g) }\end{array}$ & $\begin{array}{c}\text { Shell } \\
\text { thickness } \\
(\mathrm{mm}) \\
\end{array}$ & $\begin{array}{l}\text { Kernel } \\
\text { cavity } \\
(\mathrm{mm})\end{array}$ & $\begin{array}{c}\text { Kernel } \\
\text { percentage } \\
(\%)\end{array}$ & $\begin{array}{c}\text { Good } \\
\text { kernel } \\
(\%)\end{array}$ & $\begin{array}{c}\text { Nut } \\
\text { shape } \\
\text { index } \\
\end{array}$ \\
\hline Tombul & $35.60 \mathrm{~d}$ & $1.92 \mathrm{e}$ & 2.00 & 1.04 & $1.03 \mathrm{a}$ & $1.52 \mathrm{~b}$ & $52.24 \mathrm{c}$ & $77.50 \mathrm{~d}$ & $1.10 \mathrm{~b}$ \\
\hline Palaz & $65.28 \mathrm{bc}$ & $3.07 \mathrm{c}$ & 1.93 & 1.06 & $1.00 \mathrm{ab}$ & $1.82 \mathrm{ab}$ & $55.46 \mathrm{ab}$ & $85.67 \mathrm{~cd}$ & $1.18 \mathrm{a}$ \\
\hline Çakıldak & $80.60 \mathrm{a}$ & $3.24 \mathrm{bc}$ & 1.94 & 1.06 & $0.97 \mathrm{~b}$ & $1.61 \mathrm{ab}$ & 53.92 bc & $85.30 \mathrm{~cd}$ & $1.19 \mathrm{a}$ \\
\hline Foşa & $39.27 \mathrm{~d}$ & $2.75 \mathrm{~d}$ & 1.89 & 1.05 & $0.97 \mathrm{ab}$ & $2.10 \mathrm{a}$ & $54.17 \mathrm{bc}$ & $89.00 \mathrm{bc}$ & $1.13 a b$ \\
\hline Allahverdi & $75.66 \mathrm{ab}$ & $3.44 \mathrm{a}$ & 2.00 & 1.10 & $0.97 \mathrm{ab}$ & $1.73 \mathrm{ab}$ & $54.92 \mathrm{ab}$ & $96.00 \mathrm{ab}$ & $1.13 a b$ \\
\hline Sivri & $55.35 \mathrm{c}$ & $2.72 \mathrm{~d}$ & 2.02 & 1.13 & $0.97 \mathrm{ab}$ & $1.76 \mathrm{ab}$ & $55.59 \mathrm{ab}$ & $93.47 \mathrm{abc}$ & $1.12 \mathrm{ab}$ \\
\hline Kalınkara & $60.52 \mathrm{c}$ & $3.22 \mathrm{bc}$ & 1.96 & 1.11 & $0.96 \mathrm{~b}$ & $2.05 \mathrm{ab}$ & $56.75 \mathrm{a}$ & $91.23 \mathrm{abc}$ & $1.16 \mathrm{ab}$ \\
\hline Yassı Badem & $56.79 \mathrm{c}$ & $2.69 \mathrm{~d}$ & 2.01 & 1.11 & $0.99 \mathrm{ab}$ & $1.83 \mathrm{ab}$ & $55.13 \mathrm{ab}$ & $95.77 \mathrm{a}$ & $1.13 a b$ \\
\hline Open pollination & $75.4 \mathrm{ab}$ & $3.28 \mathrm{ab}$ & 1.90 & 1.04 & $0.95 \mathrm{~b}$ & $1.59 \mathrm{ab}$ & $54.78 \mathrm{ab}$ & $90.00 \mathrm{bc}$ & $1.18 \mathrm{a}$ \\
\hline
\end{tabular}

The differences among the treatments indicated with the same letter vertically were not significant at $\mathrm{P}<0.05$.

Table 3. Nut set, number of nuts per cluster and nut characteristics of Palaz hazelnut in response to different pollinizer cultivars in 2015.

\begin{tabular}{|c|c|c|c|c|c|c|c|c|c|}
\hline $\begin{array}{l}\text { Pollinizer } \\
\text { cultivars }\end{array}$ & $\begin{array}{c}\text { Nut set } \\
(\%)\end{array}$ & $\begin{array}{l}\text { Number of } \\
\text { nuts } \\
\text { per cluster }\end{array}$ & $\begin{array}{l}\text { Nut weight } \\
\text { (g) }\end{array}$ & $\begin{array}{c}\text { Kernel } \\
\text { weight } \\
\text { (g) }\end{array}$ & $\begin{array}{c}\text { Shell } \\
\text { thickness } \\
(\mathrm{mm}) \\
\end{array}$ & $\begin{array}{l}\text { Kernel } \\
\text { cavity } \\
(\mathrm{mm}) \\
\end{array}$ & $\begin{array}{c}\text { Kernel } \\
\text { percentage } \\
(\%)\end{array}$ & $\begin{array}{c}\text { Good } \\
\text { kernel } \\
(\%) \\
\end{array}$ & $\begin{array}{c}\text { Nut } \\
\text { shape } \\
\text { index } \\
\end{array}$ \\
\hline Tombul & $57.47 \mathrm{a}$ & $3.01 \mathrm{c}$ & $2.02 \mathrm{c}$ & $1.09 \mathrm{c}$ & $0.99 \mathrm{ef}$ & $4.39 \mathrm{~b}$ & $51.36 \mathrm{abc}$ & $70.00 \mathrm{~b}$ & $0.96 \mathrm{a}$ \\
\hline Palaz & $7.49 \mathrm{~b}$ & $1.28 \mathrm{~d}$ & $2.27 \mathrm{ab}$ & $1.33 \mathrm{a}$ & $1.14 \mathrm{~b}$ & $5.41 \mathrm{a}$ & $50.06 \mathrm{c}$ & $70.00 \mathrm{~b}$ & $0.91 \mathrm{c}$ \\
\hline Çakıldak & $46.37 \mathrm{a}$ & $2.94 \mathrm{c}$ & $2.48 \mathrm{a}$ & $1.29 \mathrm{ab}$ & $1.05 \mathrm{~cd}$ & $4.73 \mathrm{ab}$ & $52.48 \mathrm{ab}$ & $81.67 \mathrm{a}$ & $0.92 \mathrm{c}$ \\
\hline Foşa & $61.64 \mathrm{a}$ & $3.32 \mathrm{a}$ & $2.28 \mathrm{ab}$ & $1.17 \mathrm{abc}$ & $1.05 \mathrm{~cd}$ & $4.81 \mathrm{ab}$ & $52.05 \mathrm{ab}$ & $77.00 \mathrm{a}$ & $0.96 \mathrm{a}$ \\
\hline Allahverdi & $58.40 \mathrm{a}$ & $3.04 \mathrm{c}$ & $2.25 \mathrm{ab}$ & $1.14 \mathrm{bc}$ & $1.09 \mathrm{c}$ & $4.70 \mathrm{ab}$ & 51.16 bc & $78.00 \mathrm{a}$ & $0.95 \mathrm{ab}$ \\
\hline Sivri & $21.96 \mathrm{~b}$ & $1.24 \mathrm{~d}$ & $2.29 \mathrm{ab}$ & $1.25 \mathrm{abc}$ & $1.20 \mathrm{a}$ & $4.74 \mathrm{ab}$ & 50.78 bc & $45.80 \mathrm{c}$ & $0.97 \mathrm{a}$ \\
\hline Kalınkara & - & - & - & - & - & - & - & - & - \\
\hline Yassı Badem & $70.45 \mathrm{a}$ & $3.20 \mathrm{~b}$ & $2.24 \mathrm{~b}$ & $1.21 \mathrm{abc}$ & $1.03 \mathrm{de}$ & $4.43 \mathrm{~b}$ & $52.47 \mathrm{ab}$ & $82.00 \mathrm{a}$ & $0.95 \mathrm{ab}$ \\
\hline Open pollination & $72.62 \mathrm{a}$ & $3.36 \mathrm{a}$ & $2.01 \mathrm{c}$ & $1.10 \mathrm{c}$ & $0.95 \mathrm{f}$ & $4.30 \mathrm{~b}$ & $53.18 \mathrm{a}$ & $79.00 \mathrm{a}$ & $0.93 \mathrm{bc}$ \\
\hline
\end{tabular}

The differences among the treatments indicated with the same letter vertically were not significant at $\mathrm{P}<0.05$.

Table 4. Nut set, number of nuts per cluster and nut characteristics of Palaz hazelnut in response to different pollinizer cultivars in 2016.

\begin{tabular}{|c|c|c|c|c|c|c|c|c|c|}
\hline $\begin{array}{l}\text { Pollinizer } \\
\text { cultivars }\end{array}$ & $\begin{array}{c}\text { Nut set } \\
(\%)\end{array}$ & $\begin{array}{l}\text { Number of } \\
\text { nuts } \\
\text { per cluster }\end{array}$ & $\begin{array}{c}\text { Nut weight } \\
\text { (g) }\end{array}$ & $\begin{array}{l}\text { Kernel } \\
\text { weight } \\
\text { (g) }\end{array}$ & $\begin{array}{c}\text { Shell } \\
\text { thicknes } \\
\mathrm{s} \\
(\mathrm{mm})\end{array}$ & $\begin{array}{l}\text { Kernel } \\
\text { cavity } \\
(\mathrm{mm})\end{array}$ & $\begin{array}{c}\text { Kernel } \\
\text { percenta } \\
\text { ge } \\
(\%)\end{array}$ & $\begin{array}{l}\text { Good } \\
\text { kernel } \\
(\%)\end{array}$ & $\begin{array}{l}\text { Nut } \\
\text { shape } \\
\text { index }\end{array}$ \\
\hline Tombul & $50.56 \mathrm{ab}$ & $2.56 \mathrm{~d}$ & $1.83 \mathrm{e}$ & $1.01 \mathrm{c}$ & $0.95 \mathrm{~d}$ & $2.89 \mathrm{bc}$ & $54.79 \mathrm{a}$ & $73.00 \mathrm{c}$ & $0.96 \mathrm{a}$ \\
\hline Palaz & $8.47 \mathrm{c}$ & $1.38 \mathrm{f}$ & $1.87 \mathrm{de}$ & $1.12 \mathrm{bc}$ & $1.07 \mathrm{ab}$ & $2.53 \mathrm{c}$ & $51.00 \mathrm{bc}$ & $45.57 \mathrm{~d}$ & $0.89 \mathrm{c}$ \\
\hline Çakıldak & $60.52 \mathrm{a}$ & $2.72 \mathrm{c}$ & 2.02 cde & $1.11 \mathrm{bc}$ & $0.99 \mathrm{~cd}$ & $3.76 \mathrm{a}$ & $49.62 \mathrm{c}$ & $54.10 \mathrm{~d}$ & $0.91 \mathrm{bc}$ \\
\hline Foșa & $56.01 \mathrm{ab}$ & $3.16 \mathrm{~b}$ & $2.17 \mathrm{bcd}$ & $1.18 \mathrm{abc}$ & $1.02 \mathrm{abc}$ & $2.91 \mathrm{bc}$ & $52.34 \mathrm{ab}$ & $77.00 \mathrm{bc}$ & $0.95 \mathrm{ab}$ \\
\hline Allahverdi & $42.20 \mathrm{~b}$ & $2.45 \mathrm{~d}$ & $2.44 \mathrm{ab}$ & $1.33 \mathrm{a}$ & $1.08 \mathrm{a}$ & $3.19 \mathrm{abc}$ & $52.38 \mathrm{ab}$ & $79.00 \mathrm{bc}$ & $0.93 \mathrm{abc}$ \\
\hline Sivri & $39.60 \mathrm{~b}$ & $2.18 \mathrm{e}$ & 2.12 cde & $1.19 \mathrm{ab}$ & $1.00 \mathrm{bcd}$ & $2.75 \mathrm{bc}$ & $53.09 \mathrm{ab}$ & $82.10 \mathrm{~b}$ & $0.90 \mathrm{c}$ \\
\hline Kalınkara & $49.46 \mathrm{ab}$ & $2.72 \mathrm{c}$ & $2.26 \mathrm{abc}$ & $1.27 \mathrm{ab}$ & $1.03 \mathrm{abc}$ & $3.05 \mathrm{abc}$ & $54.06 \mathrm{a}$ & $83.33 \mathrm{~b}$ & $0.93 \mathrm{abc}$ \\
\hline Yassı Badem & $43.45 \mathrm{~b}$ & $2.12 \mathrm{e}$ & $2.52 \mathrm{a}$ & $1.35 \mathrm{a}$ & $1.03 \mathrm{abc}$ & $3.46 \mathrm{ab}$ & $53.65 \mathrm{ab}$ & $91.00 \mathrm{a}$ & $0.91 \mathrm{c}$ \\
\hline Open pollination & $62.57 \mathrm{a}$ & $3.47 \mathrm{a}$ & $2.19 \mathrm{bc}$ & $1.18 \mathrm{abc}$ & $1.06 \mathrm{ab}$ & $3.04 \mathrm{abc}$ & $53.95 \mathrm{a}$ & $92.00 \mathrm{a}$ & $0.95 \mathrm{ab}$ \\
\hline
\end{tabular}

The differences among the treatments indicated with the same letter vertically were not significant at $\mathrm{P}<0.05$. 
Table 5. Nut set, number of nuts per cluster and nut characteristics of Çakıldak hazelnut in response to different pollinizer cultivars in 2015.

\begin{tabular}{|c|c|c|c|c|c|c|c|c|c|}
\hline $\begin{array}{l}\text { Pollinizer } \\
\text { cultivars }\end{array}$ & $\begin{array}{c}\text { Nut set } \\
(\%)\end{array}$ & $\begin{array}{c}\text { Number of } \\
\text { nuts } \\
\text { per cluster }\end{array}$ & $\begin{array}{c}\text { Nut } \\
\text { weight } \\
\text { (g) }\end{array}$ & $\begin{array}{c}\text { Kernel } \\
\text { weight } \\
\text { (g) }\end{array}$ & $\begin{array}{c}\text { Shell } \\
\text { thickness } \\
(\mathrm{mm})\end{array}$ & $\begin{array}{c}\text { Kernel } \\
\text { cavity } \\
(\mathrm{mm})\end{array}$ & $\begin{array}{c}\text { Kernel } \\
\text { percentage } \\
(\%) \\
\end{array}$ & $\begin{array}{c}\text { Good } \\
\text { kernel } \\
(\%) \\
\end{array}$ & $\begin{array}{c}\text { Nut } \\
\text { shape } \\
\text { index }\end{array}$ \\
\hline Tombul & $69.15 \mathrm{ab}$ & $2.74 \mathrm{ab}$ & $2.30 \mathrm{~b}$ & $1.29 \mathrm{~b}$ & $1.00 \mathrm{abc}$ & $2.53 \mathrm{c}$ & $55.80 \mathrm{a}$ & $96.00 \mathrm{a}$ & $1.25 \mathrm{ab}$ \\
\hline Palaz & $74.52 \mathrm{a}$ & $2.06 \mathrm{~d}$ & $2.51 \mathrm{a}$ & $1.39 \mathrm{a}$ & $1.02 \mathrm{abc}$ & $3.24 \mathrm{ab}$ & $55.27 \mathrm{a}$ & $89.00 \mathrm{c}$ & $1.17 \mathrm{~cd}$ \\
\hline Çakıldak & $27.10 \mathrm{c}$ & $1.26 \mathrm{e}$ & $2.33 \mathrm{ab}$ & $1.30 \mathrm{~b}$ & $1.08 \mathrm{a}$ & $2.66 \mathrm{c}$ & $54.52 \mathrm{ab}$ & $95.00 \mathrm{a}$ & $1.21 \mathrm{bc}$ \\
\hline Foşa & $63.61 \mathrm{ab}$ & $2.93 \mathrm{a}$ & $2.31 \mathrm{ab}$ & $1.32 \mathrm{ab}$ & $1.04 \mathrm{ab}$ & $3.47 \mathrm{a}$ & $54.86 \mathrm{ab}$ & $87.00 \mathrm{c}$ & $1.19 \mathrm{bcd}$ \\
\hline Allahverdi & $68.54 \mathrm{ab}$ & $2.55 \mathrm{bc}$ & $2.15 \mathrm{bc}$ & $1.23 \mathrm{~b}$ & $0.94 \mathrm{c}$ & $2.47 \mathrm{~cd}$ & $55.09 \mathrm{ab}$ & $77.00 \mathrm{~d}$ & $1.18 \mathrm{~cd}$ \\
\hline Sivri & $63.86 \mathrm{ab}$ & $2.87 \mathrm{a}$ & $2.28 \mathrm{~b}$ & $1.29 \mathrm{~b}$ & $1.03 \mathrm{ab}$ & $2.83 \mathrm{bc}$ & $54.82 \mathrm{ab}$ & $92.33 \mathrm{~b}$ & $1.19 \mathrm{bcd}$ \\
\hline Kalınkara & $71.73 \mathrm{ab}$ & $2.52 \mathrm{c}$ & $1.97 \mathrm{c}$ & $1.24 \mathrm{~b}$ & $1.00 \mathrm{abc}$ & $2.61 \mathrm{c}$ & $55.57 \mathrm{a}$ & $68.67 \mathrm{e}$ & $1.14 \mathrm{~d}$ \\
\hline Yassı Badem & $81.69 \mathrm{a}$ & $2.05 \mathrm{~d}$ & $2.26 \mathrm{~b}$ & $1.24 \mathrm{~b}$ & $0.97 \mathrm{bc}$ & $2.59 \mathrm{c}$ & $54.35 \mathrm{ab}$ & $86.33 \mathrm{c}$ & $1.29 \mathrm{a}$ \\
\hline Open pollination & $36.90 \mathrm{bc}$ & $2.54 \mathrm{bc}$ & $1.76 \mathrm{~d}$ & $0.94 \mathrm{c}$ & $0.95 \mathrm{c}$ & $1.96 \mathrm{~d}$ & $53.32 \mathrm{~b}$ & $67.00 \mathrm{e}$ & $1.30 \mathrm{a}$ \\
\hline
\end{tabular}

The differences among the treatments indicated with the same letter vertically were not significant at $\mathrm{P}<0.05$.

Table 6. Nut set, number of nuts per cluster and nut characteristics of Çakıldak hazelnut in response to different pollinizer cultivars in 2016.

\begin{tabular}{|c|c|c|c|c|c|c|c|c|c|}
\hline $\begin{array}{l}\text { Pollinizer } \\
\text { cultivars }\end{array}$ & $\begin{array}{c}\text { Nut set } \\
(\%)\end{array}$ & $\begin{array}{c}\text { Number of } \\
\text { nuts } \\
\text { per cluster }\end{array}$ & $\begin{array}{c}\text { Nut } \\
\text { weight } \\
\text { (g) }\end{array}$ & $\begin{array}{c}\text { Kernel } \\
\text { weight } \\
\text { (g) }\end{array}$ & $\begin{array}{c}\text { Shell } \\
\text { thickness } \\
(\mathrm{mm})\end{array}$ & $\begin{array}{c}\text { Kernel } \\
\text { cavity } \\
(\mathrm{mm})\end{array}$ & $\begin{array}{c}\text { Kernel } \\
\text { percentage } \\
(\%)\end{array}$ & $\begin{array}{c}\text { Good } \\
\text { kernel } \\
(\%)\end{array}$ & $\begin{array}{l}\text { Nut } \\
\text { shape } \\
\text { index }\end{array}$ \\
\hline Tombul & $67.32 \mathrm{bc}$ & $2.92 \mathrm{a}$ & $2.06 \mathrm{~b}$ & $1.15 \mathrm{abc}$ & $0.95 \mathrm{ab}$ & 2.35 & $55.33 \mathrm{ab}$ & $89.50 \mathrm{ab}$ & $1.09 \mathrm{~b}$ \\
\hline Palaz & $86.82 \mathrm{a}$ & $2.38 \mathrm{c}$ & $2.07 \mathrm{~b}$ & $1.19 \mathrm{ab}$ & $0.85 \mathrm{~b}$ & 2.87 & $57.71 \mathrm{a}$ & $94.00 \mathrm{a}$ & $1.09 \mathrm{~b}$ \\
\hline Çakıldak & $32.53 \mathrm{e}$ & $2.43 \mathrm{c}$ & $2.02 \mathrm{~b}$ & $1.10 \mathrm{bc}$ & $0.95 \mathrm{ab}$ & 2.89 & $53.62 \mathrm{~b}$ & $77.50 \mathrm{~cd}$ & $1.19 \mathrm{a}$ \\
\hline Foșa & $63.85 \mathrm{bc}$ & $2.93 \mathrm{a}$ & $2.34 \mathrm{a}$ & $1.28 \mathrm{a}$ & $1.00 \mathrm{a}$ & 3.10 & $54.73 \mathrm{~b}$ & $84.00 \mathrm{bcd}$ & $1.12 \mathrm{~b}$ \\
\hline Allahverdi & $45.75 \mathrm{~d}$ & $2.61 \mathrm{~b}$ & $2.11 \mathrm{~b}$ & $1.20 \mathrm{ab}$ & $0.94 \mathrm{ab}$ & 2.99 & $56.18 \mathrm{ab}$ & $80.00 \mathrm{~cd}$ & $1.12 \mathrm{~b}$ \\
\hline Sivri & $62.65 \mathrm{c}$ & $1.90 \mathrm{e}$ & $2.11 \mathrm{~b}$ & $1.23 \mathrm{ab}$ & $0.89 \mathrm{ab}$ & 2.49 & $57.74 \mathrm{a}$ & $67.33 \mathrm{ef}$ & $1.12 \mathrm{~b}$ \\
\hline Kalınkara & $57.09 \mathrm{~cd}$ & $2.16 \mathrm{~d}$ & $2.08 \mathrm{~b}$ & $1.14 \mathrm{abc}$ & $0.93 \mathrm{ab}$ & 2.28 & $55.32 \mathrm{ab}$ & $60.00 \mathrm{f}$ & $1.12 \mathrm{~b}$ \\
\hline Yassı Badem & $76.73 \mathrm{~b}$ & $2.97 \mathrm{a}$ & $2.11 \mathrm{~b}$ & $1.18 \mathrm{abc}$ & $0.98 \mathrm{a}$ & 3.11 & $54.98 \mathrm{~b}$ & $75.50 \mathrm{de}$ & $1.13 \mathrm{~b}$ \\
\hline Open pollination & $53.48 \mathrm{~cd}$ & $2.87 \mathrm{a}$ & $1.93 \mathrm{~b}$ & $1.04 \mathrm{c}$ & $0.97 \mathrm{a}$ & 2.67 & $53.89 \mathrm{~b}$ & $85.00 \mathrm{bc}$ & $1.10 \mathrm{~b}$ \\
\hline
\end{tabular}

The differences among the treatments indicated with the same letter vertically were not significant at $\mathrm{P}<0.05$.

Table 7. Nut set, number of nuts per cluster and nut characteristics of Foşa hazelnut in response to different pollinizer cultivars in 2015.

\begin{tabular}{|c|c|c|c|c|c|c|c|c|c|}
\hline $\begin{array}{l}\text { Pollinizer } \\
\text { cultivars }\end{array}$ & $\begin{array}{c}\text { Nut set } \\
(\%)\end{array}$ & $\begin{array}{l}\text { Number of } \\
\text { nuts } \\
\text { per cluster }\end{array}$ & $\begin{array}{l}\text { Nut weight } \\
\text { (g) }\end{array}$ & $\begin{array}{c}\text { Kernel } \\
\text { weight } \\
\text { (g) }\end{array}$ & $\begin{array}{l}\text { Shell } \\
\text { thickness } \\
(\mathrm{mm})\end{array}$ & $\begin{array}{l}\text { Kernel } \\
\text { cavity } \\
(\mathrm{mm})\end{array}$ & $\begin{array}{c}\text { Kernel } \\
\text { percenta } \\
\text { ge } \\
(\%)\end{array}$ & $\begin{array}{l}\text { Good } \\
\text { kernel } \\
(\%)\end{array}$ & $\begin{array}{l}\text { Nut } \\
\text { shape } \\
\text { index }\end{array}$ \\
\hline Tombul & $24.39 \mathrm{~b}$ & $2.90 \mathrm{~d}$ & $2.97 \mathrm{a}$ & $1.46 \mathrm{a}$ & $1.23 \mathrm{a}$ & $3.82 \mathrm{de}$ & $48.60 \mathrm{~d}$ & $89.00 \mathrm{~b}$ & $1.05 \mathrm{~b}$ \\
\hline Palaz & $8.29 \mathrm{~b}$ & $1.62 \mathrm{e}$ & $2.93 \mathrm{a}$ & $1.40 \mathrm{a}$ & $1.28 \mathrm{a}$ & $4.25 \mathrm{bcd}$ & $48.82 \mathrm{~d}$ & $85.43 \mathrm{bc}$ & $1.03 \mathrm{bc}$ \\
\hline Çakıldak & $65.79 \mathrm{a}$ & $3.15 \mathrm{c}$ & $1.99 \mathrm{e}$ & $1.28 \mathrm{~b}$ & $0.76 \mathrm{~d}$ & $4.31 \mathrm{bcd}$ & $60.06 \mathrm{a}$ & $82.67 \mathrm{c}$ & $0.98 \mathrm{de}$ \\
\hline Foşa & $66.17 \mathrm{a}$ & $3.22 \mathrm{c}$ & $2.16 \mathrm{de}$ & $1.28 \mathrm{~b}$ & $0.83 \mathrm{~d}$ & $5.11 \mathrm{a}$ & $58.50 \mathrm{ab}$ & $88.67 \mathrm{~b}$ & $1.00 \mathrm{bcd}$ \\
\hline Allahverdi & $11.27 \mathrm{~b}$ & $3.22 \mathrm{c}$ & $2.57 \mathrm{~b}$ & $1.45 \mathrm{a}$ & $0.96 \mathrm{c}$ & $4.56 \mathrm{abc}$ & 56.37 b & $90.00 \mathrm{~b}$ & $1.00 \mathrm{bcd}$ \\
\hline Sivri & $64.22 \mathrm{a}$ & $3.87 \mathrm{~b}$ & $2.42 \mathrm{bc}$ & $1.27 \mathrm{~b}$ & $1.07 \mathrm{~b}$ & $3.55 \mathrm{e}$ & $50.98 \mathrm{~cd}$ & $90.00 \mathrm{~b}$ & $1.10 \mathrm{a}$ \\
\hline Kalınkara & $20.58 b$ & $1.39 \mathrm{f}$ & $2.97 \mathrm{a}$ & $1.44 \mathrm{a}$ & $1.21 \mathrm{a}$ & 3.97 cde & $48.70 \mathrm{~d}$ & $97.20 \mathrm{a}$ & $1.03 \mathrm{bc}$ \\
\hline Yassı Badem & $19.71 \mathrm{~b}$ & $3.00 \mathrm{~d}$ & $2.42 \mathrm{bc}$ & $1.47 \mathrm{a}$ & $0.85 \mathrm{~d}$ & $4.83 \mathrm{ab}$ & $59.52 \mathrm{ab}$ & $70.00 \mathrm{~d}$ & $0.95 \mathrm{e}$ \\
\hline Open pollination & $80.42 \mathrm{a}$ & $4.31 \mathrm{a}$ & $2.32 \mathrm{~cd}$ & $1.21 \mathrm{~b}$ & $1.04 \mathrm{bc}$ & 3.89 cde & $52.44 \mathrm{c}$ & $73.33 \mathrm{~d}$ & $1.04 \mathrm{bc}$ \\
\hline
\end{tabular}

Table 8. Nut set, number of nuts per cluster and nut characteristics of Foşa hazelnut in response to different pollinizer cultivars in 2016.

\begin{tabular}{|c|c|c|c|c|c|c|c|c|c|}
\hline $\begin{array}{l}\text { Pollinizer } \\
\text { cultivars }\end{array}$ & $\begin{array}{c}\text { Nut set } \\
(\%)\end{array}$ & $\begin{array}{c}\text { Number of } \\
\text { nuts } \\
\text { per cluster }\end{array}$ & $\begin{array}{c}\text { Nut } \\
\text { weight } \\
\text { (g) }\end{array}$ & $\begin{array}{c}\text { Kernel } \\
\text { weight } \\
\text { (g) }\end{array}$ & $\begin{array}{c}\text { Shell } \\
\text { thickness } \\
(\mathrm{mm})\end{array}$ & $\begin{array}{l}\text { Kernel } \\
\text { cavity } \\
(\mathrm{mm})\end{array}$ & $\begin{array}{c}\text { Kernel } \\
\text { percentage } \\
(\%)\end{array}$ & $\begin{array}{l}\text { Good } \\
\text { kernel } \\
(\%)\end{array}$ & $\begin{array}{l}\text { Nut } \\
\text { shape } \\
\text { index }\end{array}$ \\
\hline Tombul & $55.54 \mathrm{~b}$ & $3.20 \mathrm{ab}$ & $1.84 \mathrm{~d}$ & $1.22 \mathrm{de}$ & $0.90 \mathrm{c}$ & $3.36 \mathrm{ab}$ & $59.86 \mathrm{a}$ & $69.00 \mathrm{e}$ & $1.00 \mathrm{~cd}$ \\
\hline Palaz & $26.27 \mathrm{e}$ & $2.48 \mathrm{c}$ & $2.89 \mathrm{a}$ & $1.44 \mathrm{bc}$ & $1.25 \mathrm{a}$ & $3.31 \mathrm{ab}$ & $49.23 \mathrm{e}$ & $85.65 \mathrm{~cd}$ & $1.05 \mathrm{abc}$ \\
\hline Çakıldak & $51.11 \mathrm{~b}$ & $2.63 \mathrm{c}$ & $2.18 \mathrm{c}$ & $1.32 \mathrm{~cd}$ & $0.84 \mathrm{c}$ & $3.25 \mathrm{ab}$ & $60.59 \mathrm{a}$ & $79.00 \mathrm{de}$ & $0.97 \mathrm{~d}$ \\
\hline Foșa & $41.67 \mathrm{bcd}$ & $2.61 \mathrm{c}$ & $2.32 \mathrm{c}$ & $1.31 \mathrm{cde}$ & $1.04 \mathrm{~b}$ & $2.37 \mathrm{abc}$ & $55.37 \mathrm{bc}$ & $90.00 \mathrm{bc}$ & $1.10 \mathrm{a}$ \\
\hline Allahverdi & $56.60 \mathrm{~b}$ & $3.08 \mathrm{~b}$ & $2.40 \mathrm{bc}$ & $1.27 \mathrm{de}$ & $1.05 \mathrm{~b}$ & $2.30 \mathrm{bc}$ & 52.69 bcde & $87.00 \mathrm{~cd}$ & $1.06 \mathrm{abc}$ \\
\hline Sivri & $30.04 \mathrm{de}$ & $1.67 \mathrm{~d}$ & $3.07 \mathrm{a}$ & $1.60 \mathrm{a}$ & $1.30 \mathrm{a}$ & $3.41 \mathrm{a}$ & $51.23 \mathrm{de}$ & $96.25 \mathrm{ab}$ & $1.03 \mathrm{bcd}$ \\
\hline Kalınkara & 34.92 cde & $2.45 \mathrm{c}$ & $2.60 \mathrm{~b}$ & $1.49 \mathrm{ab}$ & $1.10 \mathrm{~b}$ & $3.24 \mathrm{ab}$ & $56.07 \mathrm{~b}$ & $88.33 \mathrm{~cd}$ & $1.02 \mathrm{bcd}$ \\
\hline Yassı Badem & $48.59 \mathrm{bc}$ & $2.53 \mathrm{c}$ & $2.46 \mathrm{bc}$ & $1.34 \mathrm{bcd}$ & $1.09 \mathrm{~b}$ & $2.74 \mathrm{abc}$ & $54.91 \mathrm{bcd}$ & $98.50 \mathrm{a}$ & $1.05 \mathrm{abc}$ \\
\hline Open pollination & $76.41 \mathrm{a}$ & $3.44 \mathrm{a}$ & $2.20 \mathrm{c}$ & $1.16 \mathrm{e}$ & $1.07 \mathrm{~b}$ & $1.97 \mathrm{c}$ & 52.19 cde & $91.50 \mathrm{bc}$ & $1.09 \mathrm{ab}$ \\
\hline
\end{tabular}

The differences among the treatments indicated with the same letter vertically were not significant at $\mathrm{P}<0.05$. 
Table 9. Nut set, number of nuts per cluster and nut characteristics of Allahverdi hazelnut in response to different pollinizer cultivars in 2015.

\begin{tabular}{|c|c|c|c|c|c|c|c|c|c|}
\hline $\begin{array}{l}\text { Pollinizer } \\
\text { cultivars }\end{array}$ & $\begin{array}{c}\text { Nut set } \\
(\%)\end{array}$ & $\begin{array}{c}\text { Number of } \\
\text { nuts } \\
\text { per cluster }\end{array}$ & $\begin{array}{c}\text { Nut } \\
\text { weight } \\
\text { (g) }\end{array}$ & $\begin{array}{c}\text { Kernel } \\
\text { weight } \\
\text { (g) }\end{array}$ & $\begin{array}{c}\text { Shell } \\
\text { thickness } \\
(\mathrm{mm})\end{array}$ & $\begin{array}{l}\text { Kernel } \\
\text { cavity } \\
(\mathrm{mm})\end{array}$ & $\begin{array}{c}\text { Kernel } \\
\text { percentage } \\
(\%)\end{array}$ & $\begin{array}{c}\text { Good } \\
\text { kernel } \\
(\%)\end{array}$ & $\begin{array}{c}\text { Nut } \\
\text { shape } \\
\text { index } \\
\end{array}$ \\
\hline Tombul & 79.02 & $3.72 \mathrm{~d}$ & $2.31 \mathrm{ab}$ & $1.10 \mathrm{abc}$ & $1.19 \mathrm{a}$ & $2.94 \mathrm{abc}$ & $47.07 \mathrm{bc}$ & $95.00 \mathrm{bc}$ & $1.21 \mathrm{ab}$ \\
\hline Palaz & 63.82 & $3.37 \mathrm{e}$ & $2.40 \mathrm{a}$ & $1.16 \mathrm{a}$ & $1.19 \mathrm{a}$ & $2.99 \mathrm{ab}$ & $48.51 \mathrm{ab}$ & $89.00 \mathrm{~d}$ & $1.18 \mathrm{bc}$ \\
\hline Çakıldak & 64.97 & $3.45 \mathrm{e}$ & $2.18 \mathrm{bc}$ & $1.01 \mathrm{cde}$ & $1.13 \mathrm{ab}$ & $2.57 \mathrm{bcd}$ & $46.89 \mathrm{c}$ & $90.00 \mathrm{~d}$ & $1.15 \mathrm{c}$ \\
\hline Foşa & 67.52 & $4.13 \mathrm{c}$ & $1.97 \mathrm{~d}$ & $0.95 \mathrm{e}$ & $1.10 \mathrm{~b}$ & $2.17 \mathrm{~d}$ & $48.23 \mathrm{abc}$ & $99.00 \mathrm{a}$ & $1.20 \mathrm{ab}$ \\
\hline Allahverdi & 64.26 & $2.92 \mathrm{~g}$ & $2.10 \mathrm{~cd}$ & 1.03 bcde & $1.10 \mathrm{~b}$ & $2.49 \mathrm{~cd}$ & $49.62 \mathrm{a}$ & $93.00 \mathrm{c}$ & $1.20 \mathrm{ab}$ \\
\hline Sivri & 66.76 & $5.22 \mathrm{a}$ & $2.09 \mathrm{~cd}$ & $0.99 \mathrm{de}$ & $1.08 \mathrm{~b}$ & $2.45 \mathrm{~d}$ & $47.28 \mathrm{bc}$ & $88.00 \mathrm{~d}$ & $1.25 \mathrm{a}$ \\
\hline Kalınkara & 63.63 & $3.15 \mathrm{f}$ & $2.34 \mathrm{ab}$ & $1.12 \mathrm{ab}$ & $1.13 \mathrm{ab}$ & $3.16 \mathrm{a}$ & $47.98 \mathrm{bc}$ & $97.00 \mathrm{~b}$ & $1.21 \mathrm{ab}$ \\
\hline Yassı Badem & 69.83 & $3.62 \mathrm{~d}$ & $2.22 \mathrm{bc}$ & $1.05 \mathrm{bcd}$ & $1.11 \mathrm{ab}$ & $2.47 \mathrm{~d}$ & $48.16 \mathrm{abc}$ & $97.00 \mathrm{~b}$ & $1.24 \mathrm{a}$ \\
\hline Open pollination & 83.03 & $4.91 \mathrm{~b}$ & $1.98 \mathrm{~d}$ & $0.95 \mathrm{e}$ & $1.10 \mathrm{~b}$ & $2.40 \mathrm{~d}$ & $48.60 \mathrm{ab}$ & $73.00 \mathrm{e}$ & $1.20 \mathrm{ab}$ \\
\hline
\end{tabular}

The differences among the treatments indicated with the same letter vertically were not significant at $\mathrm{P}<0.05$.

Table 10. Nut set, number of nuts per cluster and nut characteristics of Allahverdi hazelnut in response to different pollinizer cultivars in 2016.

\begin{tabular}{|c|c|c|c|c|c|c|c|c|c|}
\hline $\begin{array}{l}\text { Pollinizer } \\
\text { cultivars }\end{array}$ & $\begin{array}{c}\text { Nut set } \\
(\%)\end{array}$ & $\begin{array}{l}\text { Number of } \\
\text { nuts } \\
\text { per cluster }\end{array}$ & $\begin{array}{c}\text { Nut } \\
\text { weight } \\
\text { (g) }\end{array}$ & $\begin{array}{c}\text { Kernel } \\
\text { weight } \\
\text { (g) }\end{array}$ & $\begin{array}{c}\text { Shell } \\
\text { thickness } \\
(\mathrm{mm}) \\
\end{array}$ & $\begin{array}{l}\text { Kernel } \\
\text { cavity } \\
(\mathrm{mm})\end{array}$ & $\begin{array}{c}\text { Kernel } \\
\text { percentage } \\
(\%)\end{array}$ & $\begin{array}{l}\text { Good } \\
\text { kernel } \\
(\%)\end{array}$ & $\begin{array}{c}\text { Nut } \\
\text { shape } \\
\text { index } \\
\end{array}$ \\
\hline Tombul & $55.10 \mathrm{~b}$ & $3.42 \mathrm{c}$ & $1.65 \mathrm{~d}$ & $0.76 \mathrm{~d}$ & $1.05 \mathrm{~b}$ & 1.43 & $46.53 \mathrm{~b}$ & $84.00 \mathrm{~b}$ & $1.25 \mathrm{a}$ \\
\hline Palaz & $67.02 \mathrm{ab}$ & $2.95 \mathrm{e}$ & $2.29 \mathrm{a}$ & $1.10 \mathrm{a}$ & $1.14 \mathrm{ab}$ & 1.58 & $48.31 \mathrm{ab}$ & $91.67 \mathrm{ab}$ & $1.16 \mathrm{~b}$ \\
\hline Çakıldak & $64.35 \mathrm{ab}$ & $3.37 \mathrm{c}$ & $2.18 \mathrm{ab}$ & $1.05 \mathrm{ab}$ & $1.19 \mathrm{a}$ & 1.41 & $48.12 \mathrm{ab}$ & $91.67 \mathrm{ab}$ & $1.21 \mathrm{ab}$ \\
\hline Foşa & $74.88 \mathrm{a}$ & $3.67 \mathrm{~b}$ & $1.94 \mathrm{bc}$ & $0.96 \mathrm{bc}$ & $1.04 \mathrm{~b}$ & 1.98 & $50.23 \mathrm{a}$ & $93.35 \mathrm{a}$ & $1.22 \mathrm{ab}$ \\
\hline Allahverdi & $22.48 \mathrm{c}$ & $1.80 \mathrm{f}$ & $2.25 \mathrm{a}$ & $0.98 \mathrm{~b}$ & $1.12 \mathrm{ab}$ & 2.12 & $44.15 \mathrm{c}$ & $90.00 \mathrm{ab}$ & $1.06 \mathrm{c}$ \\
\hline Sivri & $69.20 \mathrm{ab}$ & $3.15 \mathrm{~d}$ & $2.10 \mathrm{ab}$ & $1.01 \mathrm{ab}$ & $1.10 \mathrm{ab}$ & 1.77 & $48.11 \mathrm{ab}$ & $91.50 \mathrm{ab}$ & $1.16 \mathrm{~b}$ \\
\hline Kalınkara & $56.98 \mathrm{~b}$ & $3.44 \mathrm{c}$ & $2.09 \mathrm{ab}$ & $1.01 \mathrm{ab}$ & $1.10 \mathrm{ab}$ & 1.91 & $48.61 \mathrm{ab}$ & $93.67 \mathrm{a}$ & $1.16 \mathrm{~b}$ \\
\hline Yassı Badem & $66.27 \mathrm{ab}$ & $3.49 \mathrm{bc}$ & $1.84 \mathrm{~cd}$ & $0.86 \mathrm{c}$ & $1.03 \mathrm{~b}$ & 1.74 & $46.89 \mathrm{~b}$ & $88.50 \mathrm{ab}$ & $1.20 \mathrm{ab}$ \\
\hline Open pollination & $76.97 \mathrm{a}$ & $4.36 \mathrm{a}$ & $1.96 \mathrm{bc}$ & $1.00 \mathrm{ab}$ & $1.12 \mathrm{ab}$ & 1.89 & $49.92 \mathrm{a}$ & $94.00 \mathrm{a}$ & $1.22 \mathrm{ab}$ \\
\hline
\end{tabular}

The differences among the treatments indicated with the same letter vertically were not significant at $\mathrm{P}<0.05$.

\section{Conclusion}

It was concluded based on present results that pollinizer cultivars generated significant variations in nut and kernel characteristics of hazelnuts through xenia and metaxenia effect. Effects of treatments on important yield components of hazelnuts (nut set and number of nuts per cluster) were quite remarkable. The variations in pomological characteristics might have been related also to nut load as well as pollen source. Present findings revealed that pollinator cultivars resulted in changes in nut shape. So, it will be appropriate to use pollinizer cultivars that match the main cultivars with flowering time, do not show any incompatibility and belong to the round nut group in hazelnut orchards.

\section{Acknowledgements}

Hazelnut Promotion Group and Black Sea Hazelnut and Products Exporters Union was supported the study. The authors are also thankful to Assoc. Prof. Dr. Burhan ÖZTÜRK for your help with statistical analysis and other contributions.

\section{References}

Ak, B.E., 2001. Effects of different pistacia species pollen on fruit dimension and weight in the 'Kırmız' variety, XI. Grempa Seminar on Pistachios and Almonds (2001, Zaragozai) CHİEAM, 311-314.

Anagnostakis, S.L., Devin, P., 1998. Lack of effect of pollen parent on nut weight of chesnuts, Northern Nut Growers Association Annual Report, 89: 15-17.

Balık, H.İ., Beyhan, N., 2011. Meyve türlerinde dikogami. Türkiye VI. Ulusal Bahçe Bitkileri Kongresi (4-8 Ekim 2011, Şanlıurfa) Bildirileri, 964-969.

Balık, H.İ., Balık, S.K., Köse, Ç.B., Duyar, Ö., Sıray, E., Sezer, A., Turan A., Beyhan, N., Erdoğan, V., İslam, A., Kurt H., Ak, K., Kalkıșım, Ö., 2014. Development of the new cultivars of hazelnut by selection from 'Tombul' hazelnut populations in Giresun and Trabzon provinces. International Mesopotamia Agriculture Congress (22-25 September 2014, Diyarbakır, Turkey) Proceedings, 172-179.

Balık, H.İ., Kayalak Balık, S., Beyhan, N., Erdoğan, V., 2016. Hazelnut Cultivars. Klasmat Matbaacılık, Trabzon, Turkey, $96 \mathrm{pp}$. 
Beyhan, N., 2000. Findığın döllenme biyolojisi. Ondokuzmayıs Üniversitesi Ziraat Fakültesi Dergisi, 15(2): 116-122.

Beyhan, N., Marangoz, D., 2007. An investigation of the relationship between reproductive growth and yield loss in hazelnut. Scientia Horticulturae, 113(2): 208-215.

Çakır, B., Genç, Ç., 1979. Findıkta (Corylus avellana L.) tozlanma ve tozlayıcı seçim çalışmaları. Tarımsal Araştırma Dergisi, 1(2): 125-131.

Çetiner, E., Okay, A.N., Baș, F.,1984. Yuvarlak Pomolojik Grubunda Çeşit ve Tozlayıcı Ön Seçimi. Proje sonuç raporu, Fındık Araştırma Enstitüsü, Giresun.

De Nettancourt, D., 1977. Incompatibility in angiosperms. Monographs Therotical and Applied Genetics 3. Springer Verlag, Berlin.

Denney, J.O., 1992. Xenia includes metaxenia. Hortscience, 27(7): 722-728.

Dicenta, F., Ortega, E., Canovas, J.A., Egea, J., 2002. Selfpollination vs. cross-pollination in almond: Pollen tube growth, fruit set and fruit characteristics. Plant Breeding, 121(1): 163-167.

Erdoğan, V., Mehlenbacher, S.A., 2001. Incompatibility in Wild Corylus Species. Proceedings V. International Congress on Hazelnut. Acta Horticulturae 556: 163169.

Erdoğan V., Mehlenbacher, S.A., 1997. Preliminary results on interspesific hybridization in Corylus. IV. International Symposium on Hazelnut. Acta Horticulturae 445: 65-71.

Fatahi, R., Mohammadzedeh, M., Khadivi-Khub, A., 2014. Influence of different pollen sources on nut and kernel characteristics of hazelnut. Scientia Horticulturae, 173: 15-19.

Focke, W.O., 1881. Die Pflanzen-Mischlinge:ein Beitrag zur Biologie der Gewachse. Bomtrae-ger, 510-518, Berlin.

Golzari, M., Hassani, D., Rahemi, M., Vahdati, K., 2016. Xenia and metaxenia in Persian walnut (Juglans regia L.). Journal of Nuts 7(2): 101-108.

İslam, A., Özgüven, A.I., Bostan, S.Z., Karadeniz, T., 2005. Relationships among nut characteristics in the important hazelnut cultivars. Pakistan Journal of Biological Sciences, 8(6): 914-917.

İslam, A., 2018. Hazelnut culture in Turkey. Akademik Ziraat Dergisi 7(2):259-266.

Kirkpatrick, E.M., (editor) 1987. Chambers 20th century dictionary. New ed. Chambers, Edinburgh.

Köksal, A.İ., 2002. Türk Fındık Çeşitleri. Fındık Tanıtım Grubu, Grafik Servis, Ankara,136 s.
Legave, J.V., Richard, J.C., Thermoz, J.P., Duval, H., 1997. Lauranne 'Avijor' dans la course. Fruits Legumes, 155: 36-38.

Lield, B.E., Anderson, N.O., 1993. Reproductive barriers: Cidentification, uses and circumvention. Plant Breeding Review, 11: 11-154.

Morris, W., (editor) 1976. The American heritage dictionary of the English language. Hough Mifflin, Boston.

Nawaschin, S.1898. Resultat einer Revision des Befruhtusvorganger bei Lillium martagon und Fritillaria tenella Bul. de Academia Imp. de St.Petersbou, 9:1-6.

Neufeldt, V., (editor) 1988. Webster's New World dictionary of American English. 3rd College ed. Webster's New World, New York.

Okay, A.N., Çalışkan, T., Çakırmelikoğlu, C., 1999. Fındık Genetik Kaynakları Projesi 'Allahverdi' Fındık Çeşidinin Tanımlanması. Sonuç raporu, Fındık Araştırma Enstitüsü.

Olsen, J.L., Mehlenbacher, S.A., Azarenko, A.N., 2000. Hazelnut pollination. HorTechnology, JanuaryMarch 2000 10: 1, Pollination Workshop Proceedings.

Owais, S.J., 2014. Self-incompatibility and effect of reciprocal cross and open pollination on fruit set and fruit characteristics in joardanian almond landraces. American Journal of Agricultural and Biological Sciences, 9(3): 466-476.

Reiger, R., Michaelis, A., Green, M.M., (editor) 1976. Glossary of genetics and cytogenetics, classical and molecular. 4th ed. Springer-Verlag, Berlin.

Romero, A., Tous, J., Durfort, M., Rius, M., 2003. Histology of hazelnut kernel affected by brown spots in kernel cavity physiopathy. Spanish Journal of Agricultural Research, 1(3): 47-53.

Smith, D.C., Mehlenbacher, S.A. 1994. Use of tyvek housewrap for pollination bags in breeding hazelnut (Corylus avellana L.). Hortscience 29: 8, 918.

Soule, J., 1985. Glossary for horticultural crops. Wiley, New York.

Strasburger, E., 1878. Uber polyembryonie. Zeitschr. für Naturwiss, 12: 654-678.

Swingle, W.T., 1928. Metaxenia in the date palm, possibly o hormone action by the embryo or endosperm, Journal of Heredity, 19: 257-268.

Thompson, M.M., 1979. Growth and development of the pistillate flower and nut in 'Barcelona' filbert. 
Journal of the American Society for Horticultural Science, 104: 427-432.

Vezvaei, A., Jackson, J.F., 1995. Effect of pollen parent and stages of flower development on almond nut production. Australian Journal of Experimental Agriculture, 35: 109-113.

Westwood, M.N., 1989. Temperate-zone pomology. W.H. Freeman, 373-376, New York.

Winburne, J.N., (editor) 1962. A dictionary of agricultural and allied terminology. Michigan State University Press, East Lansing, Michigan.
Xuhui, Z., Deyi, Y., Feng, Z., Xiaoming, F., Jing, T., Zhoujun, Z., 2016. A study on the xenia effect in Castanea henryi. Horticultural Plant Journal, 2(86): 301-308.

Xie, M., Liu, Z.P., 2014. Studies on pollen viability and pollen-stigma compatibility of hybrid hazelnut. Proceedings VIII. International Congress on Hazelnut. Acta Horticulturae 1052: 117-119.

Yao, Q., Mehlenbacher, S.A., 2000. Heritability, variance components and correlation of morphological and phenological traits in hazelnut. Plant Breeding, 119: 369-381. 